Bangladesh J. Agril. Res. 34(3) : 523-529, September 2009 Short Communication

\title{
SUSTAINABILITY OF ACCELERATED RICE PRODUCTION IN BANGLADESH: TECHNOLOGICAL ISSUES AND THE ENVIRONMENT
}

\begin{abstract}
MOHAMMAD A. T. CHOWDHURY ${ }^{1}$
Key Words: Sustainabiity, ecosystems, yield, urbanization, soil degradation.

Sustainable food production and achieving food security for all are among the major challenges that Bangladesh is confronted with. Food security has been and will remain a major concern for Bangladesh. Rice is the staple food of Bangladeshi people. It provides about 75 percent of the calories and 55 percent of the protein in the average daily diet (Bhuiyan et al, 2002), and ensures political stability for the country. Since the stable supply of rice has great implications for food security, many views food security as synonymous to achieve selfsufficiency in rice production (Hossain et al., 2005).
\end{abstract}

As the principal crop, rice covers about 75 percent of the total cropped area, accounts for 70 percent of the value of total crop output and constitutes 92 percent of the total foodgrains produced annually in the country. The dominance of rice in the crop sub-sector virtually assures stability in the structure of production. Major shifts in the crop diversification will be limited as long as rice is important to the diet of the nation as staple food (World Bank, 2000).

Advances in rice science and technology have enabled Bangladesh to meet food needs of the fast growing population. Acceleration of rice production has resulted in an increase in per capita availability and led to self-sufficiency by the early 1990s. Intensive rice cultivation, however, has been under some strains since then. Soil degradation is undermining the long-term capacity of irrigated and rainfed agro-ecosystems. Stress on land and water are further magnifying the issue of resource constraints to food production.

Overall, the impression of intensive rice cultivation is that the resource base for agriculture is shrinking. Failure to confront this problem will leave Bangladesh with low agricultural yields, reduced areas of good agricultural land and high expenditures on modern agricultural inputs to offset loss of land fertility. Although nutrient inputs, new crop varieties and technologies may well offset these declining conditions for the foreseeable future, the challenge of meeting human needs seems destined to grow ever more difficult.

This paper addresses the issue whether Bangladesh will be able to sustain intensive rice cultivation and further improve food security for all through selfsufficiency in production. The paper then briefly examines the factors that

${ }^{1}$ Professor, Department of Geography and Environmental Studies, University of Chittagong, Chittagong, Bangladesh. 
governs the supply side of food security and identifies the technological challenges, if the food-population balance is to be maintained, while protecting and enhancing the environment.

The study was centered on the analysis and depiction of Bangladesh Bureau of Statistics (BBS) data at the national level. Trends of rice production, area, yield and some modern inputs have been examined to depict the changes taking place over time (1971-72 to 2004-05). To analyze data and interpret the results, appropriate materials published by relevant organizations have also been studied and utilized in conjunction with the Internet resources.

Bangladesh made steady progress in rice production in the postIndependence period. Rice production increased substantially over the years following the introduction of HYV and application of modern agricultural inputs i.e., irrigation, chemical fertilizers, and pesticides. Between 1971-72 and 2004 and 2005, rice production has more than doubled-increased from 9.8 million $\mathrm{mt}$ to 252 million mt (Fig. 1). Progress in rice output can be attributed in part to the increase in average yield for boro HYV rice (Fig. 2) although after the Initial gain, yield growth for all HYV rice (aus, aman, and boro) has gradually stagnated. A modest but gradual increase in the gross area cultivated together with the shift from local varieties to HYV have accounted for a large part of the increase in rice production (Fig. 3). The area under different rice categories shows that it is mainly the expansion of boro HYV rice area that has made a significant contribution towards increased rice production during the period. However, the dependence on weather related phenomena continue to result in fluctuations of production.

In 1993-94 and 1994-95, rice production declined as a result of natural disasters (particularly floods and droughts) in the Northwest region that had become a surplus grain production region of the country. The decline in rice production in 1993-94 also reflected the farmers' response to the fall in rice price in the preceding year. This is evident by more than a 4 percent drop in fertilizer consumption, more than 2 percent reduction in area sown and a similar decline in irrigation command area (Hossain, 1999). Even the actual rice production in 2004-05 was 4.8 percent lower than that of 2003-04. This was mainly due to crop damages caused by devastating flood and cyclonic rainfall during JulySeptember 2004.

The impressive growth of rice production over the last three decades or so has generated a sense of complacency regarding Bangladesh's ability to meet the growing demand for rice. Recent trend in the growth in rice production, however, raises serious concern regarding the sustainability of the past achievements. Despite increases in input application, yields per acre have declined or stayed the same on about two-thirds of the area planted with modern varieties In the 1990s 
(Paglola, 1995). Changes of rice productivity under modern inputs though reveal some interesting points regarding self-sufficiency, it has failed to achieve the goal of sustainable production in real terms (Alam and Moral, 2006).
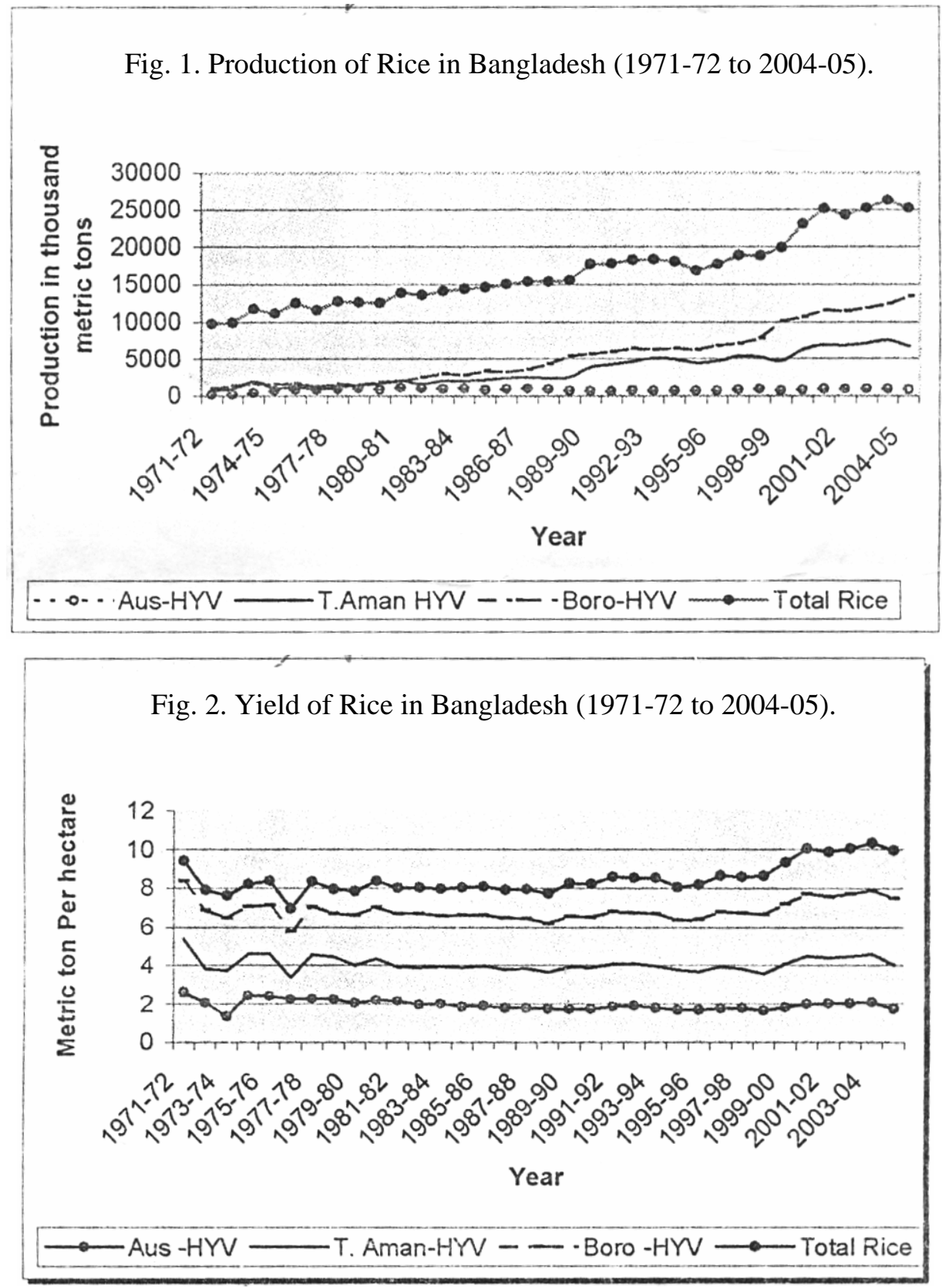


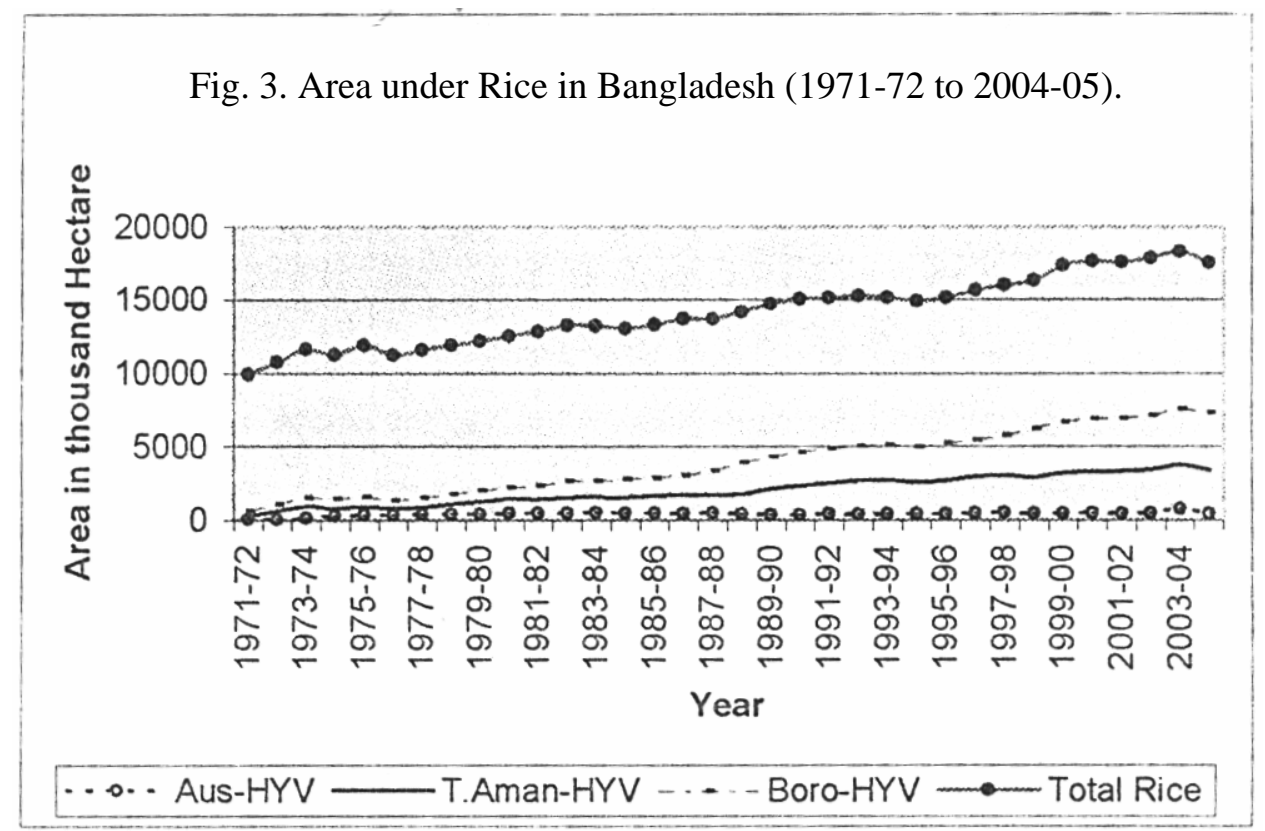

Moreover, maintaining the growth in yield even holding yields at current levels requires greater amounts of fertilizer input, implying that the quality of the underlying soil resource may be deteriorating. Fertilizer and pesticides overdoses have already been depleting soil fertility in Bangladesh. According to an estimate, about 1.8 million ha of land in Bangladesh are either on the threshold level or acute stage of zinc deficiency. Out of 27 agro-ecological zones in Bangladesh, 18 fall in the nutrient grades of poor to very poor (Ahmed and Hasanuzzaman, 1998).

Further, economic growth, industrialization and rural-urban migration are leading to rapid urbanization and concentration of people in a few large cities An important implication of growing urbanization is that some of the fertile agricultural land has to be converted to other uses. The rice field has already started declining in Bangladesh. The 1996 Agricultural Census recorded that the land area operated by rural household has declined from 9.2 million ha in 1983 to 8.2 million ha in 1996. Thus, about one million ha of arable land have been transferred out of agriculture-a net loss of 82,000 ha per annum (Halim and Rahman, 2001).

Future increases in rice production have to come from crop intensification since available cultivable land is almost fully utilized. This option is often hindered by flood and drainage problems of varying degrees and by limited access to irrigation for the majority of farmers (Khan, 1990). With rapidly growing population, per capita availability of water has been declining. On the 
other hand, conflicts among competing users of scarce water resources have become more common.

Loss of paddy due to floods and other natural disasters has also become a common phenomenon, seriously disrupting the entire economy. The experiences during the past have revealed the basic nature and vulnerability of food crop subsector. Almost every year, considerable amounts of rice are lost due to flood. Although drought is not a new hazard event for Bangladesh, the intensification of drought is now a cause of high concern. The northwestern (NW) region of Bangladesh is more prone to drought than others. The persistent drought condition in NW Bangladesh in recent decades had led to a shortfall of rice production of 3.5 million $t$ in the 1990s (Elahi, 2001).

Bangladesh will face enormous challenge by 2020 in flying to achieve food self-reliance and to ensure food security for all in the country. Demand for rice will increase with the increase in population. According to an estimate, the population of Bangladesh will be 169 million by the year 2025. As a consequence, land-man ratio will decline gradually. To feed the extra million, Bangladesh will be required to produce about 27.8 million $\mathrm{mt}$ of clean rice by the year 2025, which is roughly 21 percent higher than the production level of 2000 (Bhuiyan et al., 2002). The demand has to be met from our limited and shrinking land and water resource bases. The challenge to maintain the food-population balance is great because almost all the cultivable land in Bangladesh is in use. Therefore, a core concern is how to sustain rice productivity while protecting and enhancing the environment.

Bangladesh faces substantial obstacles in its efforts to become self sufficient in rice production. There has been a great success in rice production over the last three decades but there is a growing concern among the scientists and policy makers about how to feed the extra millions in future since the yield of MV rice is stagnated at lower level. The major challenge facing the scientific community today is how to maintain a sustained increase in real rice output despite declining natural resource base- lands and water.

Rice production can largely be sustained in Bangladesh if land and water on which it is primarily based are not degraded. Bangladesh needs to exploit the benefits of rice science more than anything else. If the successful discoveries of high breed rice can be fully exploited and integrated, Bangladesh's fortune may change positively. Maintaining a favourable demand-supply balance of rice in Bangladesh will depend on the exploitation of the productive capacity mainly in the rainfed areas. Recent advances in molecular biology, genetic engineering, bio-technology, systems models, remote sensing and Geographic Information Systems (GIS) will hopefully encourage scientists to put more effort in 
addressing the complex problems of rice cultivation in the rainfed ecosystem. Some specific concluding remarks and recommendations are as follows:

o Rice production has more than doubled over the last three decades or so, but the yield of MV rice have declined or stagnated at a lower level.

o The demand for rice will continue to increase and cannot be met from the present levels of yield and area under MV rice.

o Achieving higher yield through increased cropping intensity and varietal development of MV rice are the most logical ways of raising the total production at national level. Attention should be focused not only on irrigated but also on rainfed areas.

o Increasing supply of quality seeds and application of improved management practices (crop, soil, water, fertilizer, and pests)) at farm level should be introduced to accelerate rice production

o A 2-3 percent increase in rice production per annum has to be attained over the next few decades to feed the growing population. A technological break through in varietal development having higher yield potential, particularly for irrigated ecosystem is a must for sustaining rice production in the long term.

\section{References}

Ahmed, Q. K. and S. M. Hasanuzzaman. 1998. Agricultural growth and environment, Bangladesh Agriculture in the $21^{\text {st }}$ Century (Faruqee, R. ed.), The University Press Ltd., Dhaka, pp. 81-108.

Alam, M. S. and M. J. B. Moral. 2006. Changes of rice productivity under modern inputs and sustainable agricultural production in Bangladesh, Journal of Bangladesh National Geographical Association 31(1 \& 2): 31-42.

Bhuiyan N I., D. N. R. Paul and M. A. Jabber. 2002. FeedIng the Extra Millions by 2025: Challenges for Rice Research and Extension in Bangladesh, Proceedings of the Workshop on Modern Rice Cultivation in Bangladesh, 29-31 January. pp.4-23.

Halim, A. and Z. Rahman. 2001. Agriculture: Bangladesh Environment Outlook 2001. Centre for Sustainable Development (CFSD), Dhaka, pp. 131-147.

Hossain,Q. T. 1999. Agricultural Planning in Bangladesh, Agricultural Planning in Asia . Chowdhuuy, et al.), UN-ESCAP CGPRT Centre Monograph, 37, Bogor, 1ndonesia, pp. 105-114.

Hossain, M., F. Naher and Q. Shahabuddin. 2005. Food security and nutrition in Bangladesh: Progress and determinants. Electronic journal of Agricultural and Development Economics 2(2): 103-132.

Khan H. R. 1990. Water control and productivity, Environmental Aspects of Agricultural Development in Bangladesh (Huq, S. et al., eds.), University Press Ltd., Dhaka. pp. 125-134. 
Elahi, K. M. 2001. Drought in Bangladesh: Disaster in Bangladesh (in Nizamuddin K. ed.), STMC, University of Dhaka.

Pagiola, S. 1995. Environmental and natural resource degradation in intensive agriculture in Bangladesh, Environment Department Paper No. 15, World Bank

World Bank. 2000. Bang1adesh: A Proposed Rural Development Strategy, The University Press Ltd., Dhaka 